\title{
Structure and Heme-Independent Peroxidase Activity of a Fully-Coordinated Mononuclear Mn(II) Complex with a Schiff-Base Tripodal Ligand Containing Three Imidazole Groups
}

\author{
Shuranjan Sarkar, Dohyun Moon, ${ }^{\dagger}$ Myoung Soo Lah,,${ }^{\dagger}$ and Hong-In Lee ${ }^{*}$ \\ Department of Chemistry, Kyungpook National University, Daegu 702-701, Korea. ${ }^{*}$ E-mail: leehi@knu.ac.kr \\ ${ }^{\dagger}$ Pohang Accelerator Laboratory, Pohang, Kyungbook 790-784, Korea \\ ¥Interdisciplinary School of Green Energy, Ulsan National Institute of Science and Technology, Ulsan 689-798, Korea \\ Received August 9, 2010, Accepted September 4, 2010
}

\begin{abstract}
New complex $\left[\mathrm{Mn}(\mathrm{II}) \mathrm{H}_{1.5} \mathrm{~L}\right]_{2}\left[\mathrm{Mn}(\mathrm{II}) \mathrm{H}_{3} \mathrm{~L}\right]_{2}\left(\mathrm{ClO}_{4}\right)_{5} \cdot 3 \mathrm{H}_{2} \mathrm{O}(\mathbf{1})$, where $\mathrm{H}_{3} \mathrm{~L}$ is tris $\{2$-(4-imidazolyl)methyliminoethyl\} amine (imtren), has been prepared by reacting manganese(II) perchlorate hexahydrate with the imtren ligand in methanol. X-ray crystallographic study revealed that the imtren ligand hexadentately binds to Mn(II) ion through the three Schiff-base imine $\mathrm{N}$ atoms and three imidazole $\mathrm{N}$ atoms with a distorted octahedral geometry, and the apical tertiary amine $\mathrm{N}$ atom of the ligand pseudo-coordinates to $\mathrm{Mn}(\mathrm{II})$, forming overall a pseudo-seven coordination environment. The hydrogen-bonds between imidazole and imidazolate of $\left[\mathrm{Mn}(\mathrm{II}) \mathrm{H}_{1.5} \mathrm{~L}\right]^{0.5+}$ complex ions are extended to build a $2 \mathrm{D}$ puckered network with trigonal voids. $\left[\mathrm{Mn}(\mathrm{II}) \mathrm{H}_{3} \mathrm{~L}\right]^{2+}$ complex ions constitutes another extended 2D puckered layer without hydrogen bonds. Two layers are wedged each other to constitute overall stack of the crystal. Peroxidase activity of complex 1 was examined by observing the oxidation of 2,2'-azinobis(3-ethylbenzothiazoline)-6-sulfonic acid (ABTS) with hydrogen peroxide in the presence of complex 1 . Generation of ABTS ${ }^{*}$ was observed by UV-vis and EPR spectroscopies, indicating that the complex $\mathbf{1}$, a fully-coordinated mononuclear $\mathrm{Mn}(\mathrm{II})$ complex with nitrogen-only ligand, has a heme-independent peroxidase activity.
\end{abstract}

Key Words: Manganese, Schiff bases, X-ray diffraction, Antioxidant

\section{Introduction}

Peroxidases, protecting cells against oxidative stress, catalyze the oxidation of broad range of substrates by hydrogen peroxide. Most peroxidases found until now contain the heme prosthetic groups which are situated to mediate two-electron redox reaction for the peroxidase activities. ${ }^{1}$ Among the peroxidases, a manganese peroxidase containing both the heme and manganese ion was discovered two decades ago. Although the ferric heme was found to play the primary role for the catalytic activity and manganese ion was found to be a preferred substrate in the enzyme, ${ }^{2-4}$ heme-independent peroxidase activity was also observed. ${ }^{5}$ Manganese-substituted carbonic anhydrase, which is originally a zinc metalloenzyme that catalyzes the hydration of carbon dioxide to bicarbonate, was recently revealed to act as a peroxidase. ${ }^{6}$ These led considerable interest in the role of manganese ion for the peroxidase action which requires two electrons oxidized state of catalytic center from the resting state.

Previously, Bermejo et al. synthesized manganese complexes with a Schiff-base ligand resembling salen (=bis(salicylaldehyde)-ethylenediamine) to mimic manganese peroxidase activity. ${ }^{7,8}$ They suggested that highly symmetric environments of the metal center could dimerize by itself or via exogenous axial ligand during the catalytic process, fulfilling the requirements of the peroxidase activity. ${ }^{7-9}$ Guilherme et al. recently reported a mononuclear manganese(II) complex, fully-coordinated by two $N, N$-bis(2-pyridylmethyl)amine (bmpa) ligands, to exhibit catalase-like function. ${ }^{10}$ The authors proposed that one of the two pyridyl groups in one of two bmpa ligands was labile to form a high valent $\mathrm{Mn}(\mathrm{IV})=\mathrm{O}$ intermediate or to form a dimer bridged by a hydrogen peroxide for the catalytic pro- cess. These clearly demonstrate that mononuclear manganese complexes can enhance the reactions which require two electron transfer, though many dinuclear manganese complexes have been synthesized to model such kind of reactions. ${ }^{11,12}$

To understand the mechanism of peroxidase activity by mononuclear manganese complexes, we have searched ligands which are potential to chelate a metal ion to form highly symmetric octahedral geometry as well as contain labile donor atoms. Tris $\{$ 2-(4-imidazolyl)methyliminoethyl $\}$ amine (imtren $=\mathrm{H}_{3} \mathrm{~L}$, where $\mathrm{L}^{3-}$ is triply deprotonated imtren) is a tripodal, potentially heptadentate, ligand with three imidazole groups, three imine nitrogens, and the pivotal tertiary nitrogen. Structures and characteristics of several $\mathrm{M}$ (imtren) complexes, where $\mathrm{M}=\mathrm{Co}$ (III), $\mathrm{Fe}(\mathrm{II}), \mathrm{Fe}(\mathrm{III}), \mathrm{Mg}(\mathrm{II})$, and $\mathrm{Ru}(\mathrm{II})$, have been reported. ${ }^{13-20}$ In those, the imtren ligand hexadentately coordinates to the metal ions, forming highly symmetric octahedral geometries. For $\mathrm{Mn}(\mathrm{II})$ ion, using the methylated imtren ligand at the 4-position of the imidazole ring, $\mathrm{Mn}$ (II) complexes have been synthesized and structurally characterized but $\mathrm{Mn}$ (II)(imtren) has not been structurally characterized and its reactivity has not reported. ${ }^{21}$ We present here the synthesis, structure, and peroxidase activity of $\mathrm{Mn}(\mathrm{II})($ imtren). Peroxidase activity of the complex was monitored using 2,2'-azinobis(3-ethylbenzothiazoline)-6-sulfonic acid (ABTS). ${ }^{22} \mathrm{We}$ found that $\mathrm{Mn}$ (II)(imtren) indeed displays peroxidase activity. This may be the first time discovered from a fully-coordinated mononuclear manganese complex with a nitrogen-donor-only ligand.

\section{Experimental}

Materials. Following chemicals were purchased from co- 
mmercial sources and were used without further purification: Tris(2-aminoethyl)amine, 4(5)-imidazolecarboxaldehyde, magnaness(II) perchlorate hexahydrate, and the diammonium salt of 2,2'-azinobis(3-ethylbenzothiazoline)-6-sulfonic acid (ABTS) from Sigma-Aldrich Chemical, and hydrogen peroxide from Junsei Chemical. All solvents were purified before use according to the standard procedures.

Caution! Perchlorate salts of metal complexes with organic ligands are potentially explosive. Only small quantities of material should be prepared, and the samples should be handled with care.

Preparation of tris $\{2$-(4-imidazolyl)methyliminoethyl $\}$ amine (imtren $\left.=\mathbf{H}_{3} \mathbf{L}\right)$. The imtren ligand was prepared by the literature method. ${ }^{19}$ A solution of 4-imidazolecarboxaldehyde $(0.59 \mathrm{~g}$, $6.0 \mathrm{mmol}$ ) dissolved in $20 \mathrm{~mL}$ of dried methanol was added to a magnetically stirred solution of tris(2-aminoethyl)amine $(0.31 \mathrm{~g}$, $2.0 \mathrm{mmol}$ ) dissolved in $10 \mathrm{~mL}$ of freshly dried methanol. The mixture solution was refluxed for 6 hours. A yellow solid, obtained from vacuum evaporation, was washed several times with a 1:25 mixture of methanol and acetonitrile. The solid was dried under vacuum at ambient temperature. Yield: $90 \%, \mathrm{mp}>200^{\circ} \mathrm{C}$. The imtren ligand was identified by FT-IR recorded from $\mathrm{KBr}$ pellet and ${ }^{1} \mathrm{H}$ NMR recorded in $\mathrm{CD}_{3} \mathrm{OD}$ at $25{ }^{\circ} \mathrm{C}$, showing identical features to the previously reported data. ${ }^{19}$

Synthesis of $\left[\mathrm{Mn}(\mathrm{II}) \mathrm{H}_{1.5} \mathrm{~L}\right]_{2}\left[\mathrm{Mn}(\mathrm{II}) \mathrm{H}_{3} \mathrm{~L}\right]_{2}\left(\mathrm{ClO}_{4}\right)_{5} \cdot \mathbf{3} \mathrm{H}_{2} \mathrm{O}$ (1). 4-Imidazolecarboxaldehyde $(0.59 \mathrm{~g}, 6.0 \mathrm{mmol})$ and tris(2aminoethyl)amine $(0.31 \mathrm{~g}, 2.0 \mathrm{mmol})$ were refluxed in $25 \mathrm{~mL}$ of methanol 2 hours to give a yellow solution. After cooling the solution, a solution of $\mathrm{Mn}\left(\mathrm{ClO}_{4}\right)_{2} \cdot 6 \mathrm{H}_{2} \mathrm{O}(0.51 \mathrm{~g}, 2.0 \mathrm{mmol})$ dissolved in $10 \mathrm{~mL}$ dry methanol was added drop by drop to the yellow solution and refluxed 2 hours (Scheme 1). After cooling the solution, pale yellow crystalline powders $(1.0 \mathrm{~g})$ were collected by filtration. The powder $(0.03 \mathrm{~g})$ was again dissolved in dry methanol $(5 \mathrm{~mL})$ and taken in a test tube with diethyl ether $(5 \mathrm{~mL})$. Suitable crystals for X-ray analysis were obtained from the solution after one week. Elemental analysis calculated for $\mathrm{C}_{72} \mathrm{H}_{96} \mathrm{Cl}_{5} \mathrm{Mn}_{4} \mathrm{~N}_{40} \mathrm{O}_{23}$ (mol. wt. = 2286.90): C, 37.82\%; H, $4.23 \%$; N, 24.50\%. Found: C, 38.07\%; H, 4.48\%; and N, $24.30 \%$. FAB MS analysis: $m / z$, ion, base; (+ ion mode) 434.3, $\left[\mathrm{Mn}(\mathrm{II}) \mathrm{H}_{2} \mathrm{~L}\right]^{+}, 100 \%, 534.3,\left[\mathrm{MnH}_{3} \mathrm{~L}+\left(\mathrm{ClO}_{4}\right)\right]^{+}, 80 \%$.

Peroxidase-activity test. Peroxidase activity of $\mathrm{Mn}$ (II)(imtren) was tested by observing the oxidation of the ABTS with $\mathrm{H}_{2} \mathrm{O}_{2}$ in the presence of the complex $1 .^{9,22}$ A $1.5 \times 10^{-6} \mathrm{M}$ methanolic solution of $\mathrm{Mn}(\mathrm{II})($ imtren $)\left(1 \mathrm{~mL}, 1.5 \times 10^{-9} \mathrm{~mol}\right)$ was added to the mixture of $7.5 \times 10^{-5} \mathrm{M}$ aqueous solution of ABTS $(1 \mathrm{~mL}$, $\left.7.5 \times 10^{-8} \mathrm{~mol}\right)$ and $7.5 \times 10^{-4} \mathrm{M}$ aqueous solution of $\mathrm{H}_{2} \mathrm{O}_{2}(1 \mathrm{~mL}$, $\left.7.5 \times 10^{-7} \mathrm{~mol}\right)$. The formation of the $\mathrm{ABTS}^{+\bullet}$ cation is followed by the absorption peak at $\lambda_{\max }=650 \mathrm{~nm}\left(\varepsilon=12000 \mathrm{M}^{-1} \mathrm{~cm}^{-1}\right)$.

Crystallographic data collection and refinement of the structure. A crystal of 1 was coated with Paratone oil and the diffraction data measured at $100 \mathrm{~K}$ with synchrotron radiation $(\lambda=$ $0.70000 \AA$ ) on a 4AMXW ADSC Quantum-210 detector with a Pt-coated Si double crystal monochromator at the Pohang Accelerator Laboratory, Korea. The ADSC Quantum-210 ADX program $^{23}$ was used for data collection, and HKL2000 (Ver. $0.98 .698 \mathrm{a})^{24}$ was used for cell refinement, reduction and absorption correction.

The crystal structure of complex 1 was solved by the direct method and refined by full-matrix least-squares calculation with the SHELXTL software package. ${ }^{25}$ Two Mn(II) complex ions and $\mathrm{a} \mathrm{ClO}_{4}{ }^{-}$ion were identified on the crystallographic threefold axes and an additional $\mathrm{ClO}_{4}{ }^{-}$ion site of a half site occupancy or a water molecule of a half site occupancy in the same site were found, forming an asymmetric unit. All nonhydrogen atoms were refined anisotropically. The hydrogen atoms attached to $\mathrm{N}$ or $\mathrm{C}$ atoms were assigned isotropic displacement coefficients $\mathrm{U}(\mathrm{H})=1.2 \mathrm{U}(\mathrm{N}$ or $\mathrm{C})$, and their coordinates were allowed to ride on their respective atoms. The hydrogen atoms attached to the solvent water molecule were not included in the least-square refinement. The geometry of the $\mathrm{ClO}_{4}{ }^{-}$ion of the partial occupancy was restrained using DFIX and DANG commands of the SHELXTL software during the least-squares refinement. Refinement of the structure converged at a final $R_{1}=0.0505, w R_{2}=0.1319$ for 3006 reflections with $I>2 \sigma(I)$; $R_{1}=0.0535, w R_{2}=0.1337$ for all 3251 reflections. The largest difference peak and hole were 0.398 and $-0.506 \mathrm{e} \cdot \AA^{-3}$, respectively. A summary of the crystal and some crystallography data is given in Table 1. CCDC-764395 contains the supplementary crystallographic data for this paper. The data can be obtained free of charge at www.ccdc.cam.ac.uk/conts/retrieving. html or from the Cambridge Crystallographic Data Centre, 12, Union Road, Cambridge CB2 1EZ, UK.

Physical measurements. Fourier transform infrared (FT-IR) spectra of samples was recorded with a Bruker IFS 66v FT-IR spectrophotometer in the region of $400 \mathrm{~cm}^{-1}$ to $4000 \mathrm{~cm}^{-1}$ using $\mathrm{KBr}$ pellets and visible electronic spectra was recorded with a Scinco UV S-2100 spectrophotometer. The elemental analysis was done using a Perkin-Elmer $2400 \mathrm{CHN}$ analyzer. X-Band ( $9 \mathrm{GHz}$ ) EPR spectra were recorded on a Jeol JES-TE300 ESR spectrometer using 100-kHz field modulation. Low temperature spectra were obtained using a Jeol ES-DVT3 variable temperature controller.

\section{Results and Discussion}

Synthesis of $\left[\mathrm{Mn}(\mathrm{II}) \mathrm{H}_{1.5} \mathrm{~L}\right]_{2}\left[\mathrm{Mn}(\mathrm{II}) \mathrm{H}_{3} \mathrm{~L}\right]_{2}\left(\mathrm{ClO}_{4}\right)_{5} \cdot \mathbf{3 \mathrm { H } _ { 2 }} \mathrm{O}$ (1). Solution of tris(2-aminoethyl)amine (tren) and 4-imidazolcarboxaldehyde were refluxed in dry methanol to yield the yellow tripodal Schiff-base product, imtren. The purified ligand in methanol exhibited $\lambda_{\max }$ at $290 \mathrm{~nm}$ of UV absorbance spectra. In situ reaction of manganese(II) perchlorate hexahydrate without further separation of the ligand in dry methanol solution formed pale yellow solid complex (Scheme 1). The complex was soluble in $\mathrm{CH}_{3} \mathrm{OH}, \mathrm{DMF}$, and DMSO, respectively. Crystals were obtained by the slow diffusion of diethyl ether to the methanol solution of the complex.

The initial characterization of complex was carried out by IR spectrum. The most useful regions for examination in the IR were the $\mathrm{N}-\mathrm{H}, \mathrm{C}=\mathrm{N}$, and perchlorate regions. The IR spectra of complex 1 showed the characteristic absorption bands attributable to the imidazole $v_{\mathrm{N}-\mathrm{H}}\left(3446 \mathrm{~cm}^{-1}\right)$, imine $v_{\mathrm{C}=\mathrm{N}}(1631-$ $\left.1457 \mathrm{~cm}^{-1}\right)$, and perchlorate $v_{\mathrm{Cl}-\mathrm{O}}(1080-1010$ and $636-625$ $\left.\mathrm{cm}^{-1}\right)$. In addition to the $v_{\mathrm{N}-\mathrm{H}}$ and $v_{\mathrm{C}=\mathrm{N}}$, the IR exhibits a broad band at 2180-1755 $\mathrm{cm}^{-1}$ and a weaker one at $2432 \mathrm{~cm}^{-1}$. $13,15,20,21$ These bands have been observed in hemi-deprotonated tren imidazole complex and might be attributed to intermolecular 


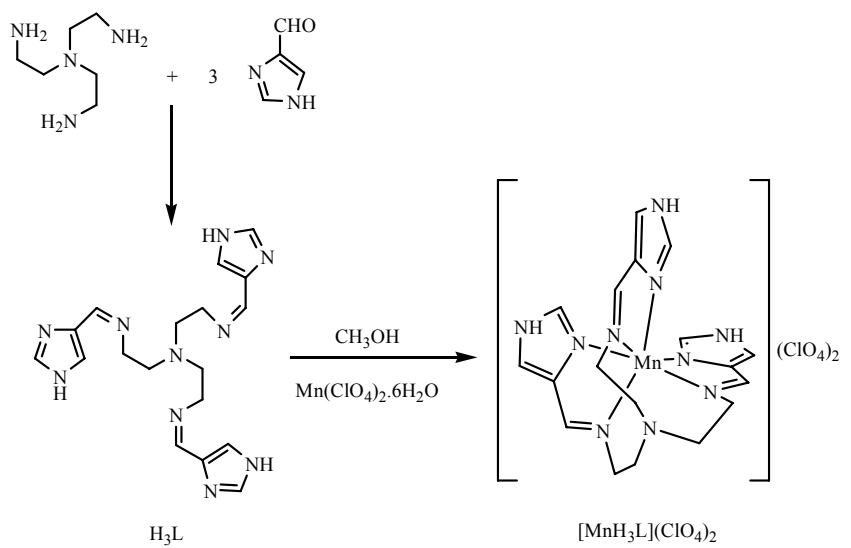

Scheme 1

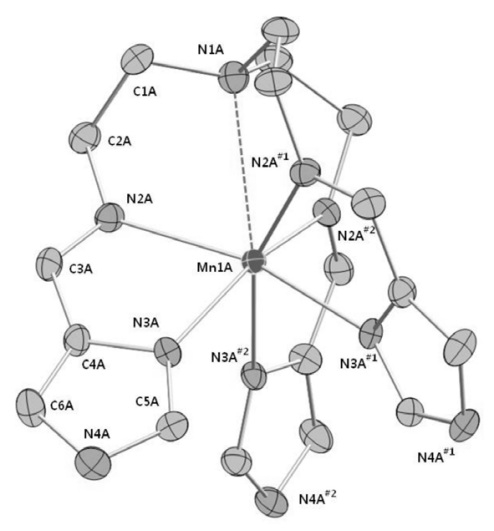

Figure 1. ORTEP diagram of $\left[\mathrm{Mn}^{1 \mathrm{~A}}(\mathrm{II}) \mathrm{H}_{1.5} \mathrm{~L}\right]^{0.5+}$ of complex 1 with $50 \%$ probability ellipsoids and atom numbering scheme. Hydrogen atoms have been omitted for clarity. Symmetry transformations used to generate equivalent atoms: ${ }^{\# 1}-y+1, x-y+1, z^{\# 2}-x+y,-x+1, z$.

hydrogen bonding. ${ }^{21,26}$ Direct evidence of an intermolecular hydrogen bonding interaction is seen in the structure of the complex and is discussed in the structure section. Imine absorptions are observed at $1631 \mathrm{~cm}^{-1}, 1526 \mathrm{~cm}^{-1}$ and $1456 \mathrm{~cm}^{-1}$.

Crystal structure of complex 1. Crystallographic study of complex 1 revealed two $\mathrm{Mn}$ (II) complex ions and $\mathrm{ClO}_{4}{ }^{-}$ion on the crystallographic three fold axes, and an additional $\mathrm{ClO}_{4}{ }^{-}$ ion site of a half site occupancy or a water molecule of a half site occupancy in the same site. Overall the structure of the crystal can be viewed as a composition of $\left[\mathrm{Mn}^{1 \mathrm{~A}}(\mathrm{II}) \mathrm{H}_{1.5} \mathrm{~L}\right]^{0.5+}$, $\left[\mathrm{Mn}^{1 \mathrm{~B}}(\mathrm{II}) \mathrm{H}_{3} \mathrm{~L}\right]^{2+}, 2.5 \mathrm{ClO}_{4}^{-}$, and $1.5 \mathrm{H}_{2} \mathrm{O}$.

Figure 1 depicts the ORTEP drawing of one of the two asymmetric $\mathrm{Mn}(\mathrm{II})$ centers in complex $\mathbf{1}$ and the crystallographic data of 1 are listed in Table 1. Imtren ligand binds to $\mathrm{Mn}(\mathrm{II})$ ion through three Schiff-base imine N atoms and three imidazole $\mathrm{N}$ atoms with distorted octahedral geometry. The distance from the $\mathrm{Mn}(\mathrm{II})$ ion to the apical tertiary amine $\mathrm{N}$ atom of the ligand is 2.824(3) $\AA$, suggesting pseudo-coordination (see below). The $\mathrm{Mn}(\mathrm{II})$ complex shows $C_{3}$ symmetry about its $\mathrm{Mn}$ (II)- $\mathrm{N}_{\text {amine }}$ axis. Imtren, an achiral tripodal ligand, can arrange around $\mathrm{Mn}$ (II) with screw type to generate a chiral complex with either a $\Delta$ or $\Lambda$ absolute configuration. The CD (circular dichroism) spectrum of the methanolic solution of complex 1 did not show
Table 1. Crystal data and structure refinement for complex 1

\begin{tabular}{ll}
\hline Empirical formula & $\mathrm{C}_{72} \mathrm{H}_{96} \mathrm{Cl}_{5} \mathrm{Mn}_{4} \mathrm{~N}_{40} \mathrm{O}_{23}$ \\
Formula weight & 2286.90 \\
Temperature, $\mathrm{K}$ & $100(2)$ \\
Wavelength, $\AA$ & 0.70000 \\
Crystal system & Rhombohedral \\
Space group & $R 32$ \\
$a, \AA$ & $11.9715(17)$ \\
$b, \AA$ & $11.9715(17)$ \\
$c, \AA$ & $64.197(13)$ \\
$\alpha,{ }^{\circ}$ & 90 \\
$\beta,{ }^{\circ}$ & 90 \\
$\gamma{ }^{\circ}$ & 120 \\
Volume, $\AA^{3}$ & $7962(2)$ \\
$Z$ & 3 \\
Independent Reflections & $3251[\mathrm{R}($ int $)=0.0635]$ \\
Absorption correction & Empirical \\
Goodness-of-fit on $F^{2}$ & 1.060 \\
Final $R$ indices $[I>2 \sigma(I)]^{a, b}$ & $R_{1}=0.0505, w R_{2}=0.1319$ \\
$\mathrm{R}$ indices (all data) & $R_{1}=0.0535, w R_{2}=0.1337$ \\
Largest diff. peak and hole, e $\cdot \AA^{-3}$ & 0.398 and -0.506 \\
${ }^{a} R_{1}=\Sigma|| F_{0 \mid}|-| F_{c}|| \Sigma\left|F_{0}\right|,{ }^{b} w R_{2}=\left[\Sigma w\left(F_{0}{ }^{2}-F_{c}{ }^{2}\right)^{2} / \Sigma w F_{0}{ }^{4}\right]^{1 / 2}$
\end{tabular}

Table 2. Selected bond lengths $[\AA]$ and angles $\left[{ }^{\circ}\right]$ for complex $\mathbf{1}$

\begin{tabular}{|c|c|c|c|}
\hline \multicolumn{2}{|c|}{$\left[\mathrm{Mn}^{1 \mathrm{~A}}(\mathrm{II}) \mathrm{H}_{1.5} \mathrm{~L}\right]^{0.5+}$} & \multicolumn{2}{|c|}{$\left[\mathrm{Mn}^{1 \mathrm{~B}}(\mathrm{II}) \mathrm{H}_{3} \mathrm{~L}\right]^{2+}$} \\
\hline \multicolumn{4}{|c|}{ Bond lengths ( $\AA)$} \\
\hline Mn1A-N2A & $2.278(3)$ & Mn1B-N2B & $2.255(3)$ \\
\hline Mn1A-N3A & $2.267(3)$ & Mn1B-N3B & $2.286(3)$ \\
\hline Mn1A-N1A & $2.824(3)$ & Mn1B-N1B & $2.929(3)$ \\
\hline \multicolumn{4}{|c|}{ Bond angles $\left(\left(^{0}\right)^{a}\right.$} \\
\hline N2A-Mn1A-N2A $\# 1$ & $104.43(8)$ & N2B-Mn1B-N2B $\# 3$ & $102.78(10)$ \\
\hline N3A-Mn1A-N3A & $85.11(11)$ & N3B-Mn1B-N3B ${ }^{\# 3}$ & $88.86(12)$ \\
\hline N2A-Mn1A-N3A & $73.22(11)$ & N2B-Mn1B-N3B & $73.40(12)$ \\
\hline $\mathrm{N} 2 \mathrm{~A}-\mathrm{Mn} 1 \mathrm{~A}-\mathrm{N} 3 \mathrm{~A}^{\# 2}$ & $97.41(11)$ & N2B-Mn1B-N3B ${ }^{\# 4}$ & $95.65(12)$ \\
\hline N2A-Mn1A-N3A & $157.82(11)$ & N2B-Mn1B-N3B & $161.55(13)$ \\
\hline
\end{tabular}

${ }^{a}$ Symmetry transformations used to generate equivalent atoms: ${ }^{\# 1}-\mathrm{y}+1$, $\mathrm{x}-\mathrm{y}+1, \mathrm{z},{ }^{\# 2}-\mathrm{x}+\mathrm{y},-\mathrm{x}+1, \mathrm{z},{ }^{\# 3}-\mathrm{x}+\mathrm{y}+1,-\mathrm{x}+1, \mathrm{z},{ }^{\# 4}-\mathrm{y}+1, \mathrm{x}-\mathrm{y}, \mathrm{z}$

any significant intensity and Flack parameter for the crystal is near 0.5 , suggesting that the crystal is a racemic twined crystal.

Table 2 lists selected bond lengths and bond angles with their standard deviations in parentheses for two $\mathrm{Mn}$ (II) centers. Both Mn(II) centers mostly resemble each other with slightly different bond lengths and bond angles. $\mathrm{Mn}-\mathrm{N}$ bond lengths are $2.255(3)-2.286(3) \AA$. These lengths are longer than the previously reported $\mathrm{Fe}-\mathrm{N}$ bond lengths of other octahedral $\mathrm{Fe}(\mathrm{III})$ (imtren) $\left(\mathrm{d}^{5}\right)$ complexes, where $\mathrm{d}(\mathrm{Fe}-\mathrm{N})=2.060(3)-2.118(3) \AA$ for the high-spin $\left[\mathrm{Fe}(\mathrm{III}) \mathrm{H}_{3} \mathrm{~L}\right]^{3+}, \mathrm{d}(\mathrm{Fe}-\mathrm{N})=1.941(2)-1.990 \AA$ for the low-spin $\left[\mathrm{Fe}(\mathrm{III}) \mathrm{H}_{3} \mathrm{~L}\right]^{3+}$, and d(Fe-N) $=1.917(2)-2.023$ (2) $\AA$ for low-spin [Fe(III)L]. ${ }^{14,17}$ The observed Mn-N bond lengths suggest $\mathrm{Mn}$ (II) ions of complex 1 have the high-spin $\left(\mathrm{S}=5 / 2, \mathrm{t}_{2 \mathrm{~g}}{ }^{3} \mathrm{e}_{\mathrm{g}}{ }^{2}\right)$ electron configuration, considering Shannon's ionic radii of hexacoordinate $\mathrm{Fe}(\mathrm{III})$ and $\mathrm{Mn}(\mathrm{II}) ; 0.645 \AA$ for high-spin Fe(III), $0.55 \AA$ for low-spin Fe(III), $0.83 \AA$ for highspin Mn(II), and $0.67 \AA$ for low-spin Mn(II). ${ }^{27}$ This is also con- 


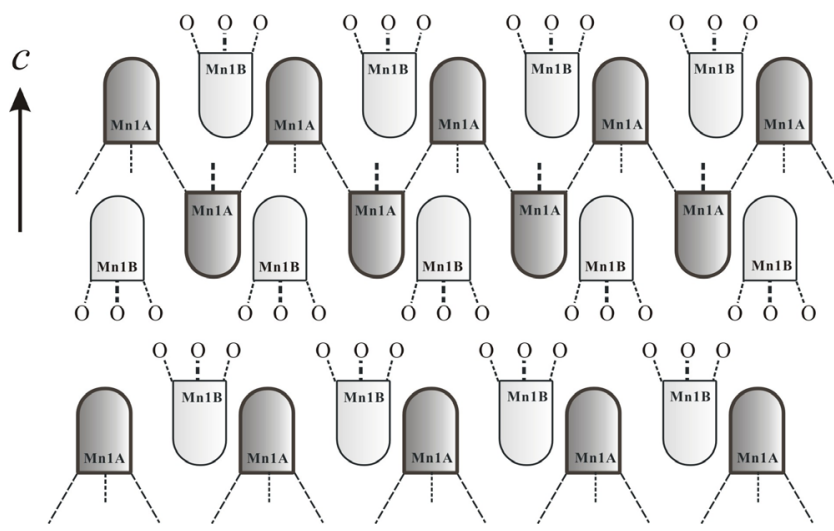

Figure 2. Schematic diagram displaying the arrangement and hydrogen-bond network of complex 1 . Dotted lines represent the hydrogen bonds of $\mathrm{N}-\mathrm{H} \cdots \mathrm{N}$ or $\mathrm{N}-\mathrm{H} \cdots \mathrm{O}$. O's represent oxygen atoms of water molecules or $\mathrm{ClO}_{4}^{-}$ions. Mn1A and $\mathrm{Mn} 1 \mathrm{~B}$ represent $\left[\mathrm{Mn}^{1 \mathrm{~A}} \mathrm{H}_{1.5} \mathrm{~L}\right]^{0.5+}$ and $\left[\mathrm{Mn}^{1 \mathrm{~B}} \mathrm{H}_{3} \mathrm{~L}\right]^{2+}$ complex ions, respectively. Arrow indicates the $c$-axis direction of the crystal unit cell.

Table 3. Hydrogen bonds for complex $1\left[\AA\right.$ and $\left.{ }^{\circ}\right]$

\begin{tabular}{|c|c|c|c|c|}
\hline $\mathrm{D}-\mathrm{H} \cdot \cdots \mathrm{A}^{a}$ & $d(D-A)$ & $\mathrm{d}(\mathrm{H} \cdots \mathrm{A})$ & $d(D \cdots A)$ & $<$ DHA) \\
\hline N4A-H4A $\cdots$ N4A $A^{\# 5}$ & 0.88 & 1.81 & $2.684(6)$ & 175.8 \\
\hline N4B-H4B $\cdots \mathrm{O} 1 \mathrm{~W}^{\# 6}$ & $0.96(6)$ & $1.94(6)$ & $2.792(13)$ & $147(5)$ \\
\hline N4B-H4B $\cdots$ O2B ${ }^{\# 6}$ & $0.96(6)$ & $2.46(6)$ & $3.066(13)$ & $121(4)$ \\
\hline
\end{tabular}

${ }^{a}$ Symmetry transformations used to generate equivalent atoms: ${ }^{\# 5} \mathrm{x}-\mathrm{y}+1$, $-\mathrm{y}+2,-\mathrm{z},{ }^{\sharp 6}-\mathrm{y}+2, \mathrm{x}-\mathrm{y}+1, \mathrm{z}$

firmed by EPR of complex 1. (see Figure 6) The distance from the $\mathrm{Mn}(\mathrm{II})$ ion to the apical tertiary amine $\mathrm{N}$ atom of the ligand is found to be 2.824(3)-2.929(3) $\AA$ in complex 1. In the crystal of $\left.\left[\mathrm{Fe}(\mathrm{II}) \mathrm{H}_{3} \mathrm{~L}\right)\right][\mathrm{Fe}(\mathrm{III}) \mathrm{L}]\left(\mathrm{BF}_{4}\right)_{2}$, this distance was 3.075(2) $\AA$ in the high-spin [Fe(III)L] site of $\left.\left[\mathrm{Fe}(\mathrm{II}) \mathrm{H}_{3} \mathrm{~L}\right)\right][\mathrm{Fe}(\mathrm{III}) \mathrm{L}]\left(\mathrm{BF}_{4}\right)_{2}$ without forming a bond. ${ }^{17}$ Considering the ionic radii of the high-spin $\mathrm{Mn}(\mathrm{II})$ and $\mathrm{Fe}(\mathrm{III})$, it is suggestive that there is a pseudo-coordination between $\mathrm{Mn}(\mathrm{II})$ and the apical tertiary amine $\mathrm{N}$ atom in the $\mathrm{Mn}$ (II) centers of complex 1.

Figure 2 shows the overall stack and arrangement of Mn(II) centers. Mn1A centers $\left(=\left[\mathrm{Mn}^{1 \mathrm{~A}} \mathrm{H}_{1.5} \mathrm{~L}\right]^{0.5+}\right)$ are connected by hydrogen bonds between imidazole and imidazolate of $\mathrm{N}_{\text {imid }} \mathrm{H} \cdots$... $\mathrm{N}_{\text {imid. }}$. Details of the hydrogen bonds are listed in Table 3.

Each Mn1A center is hydrogen-bonded to three Mn1A centers residing in a nearby layer, forming a puckered 2D network. Mn1B center $\left(=\left[\mathrm{Mn}^{1 \mathrm{~B}} \mathrm{H}_{3} \mathrm{~L}\right]^{2+}\right)$ has three hydrogen bonds to $\mathrm{O}$ atoms of water molecule or $\mathrm{ClO}_{4}{ }^{-}$ion, but these hydrogen bonds are not further extended. Two arrangements of Mn1A and Mn1B centers are wedged each other along the $c$-axis to constitute overall stack.

Figure 3 shows two pairs of Mn1A centers and their 2D network. The capped tripod-shaped Mn1A centers are hydrogen-bonded in a tail-to-tail mode and array in an up-and-down manner repeatedly to honeycomb an extended 2D puckered network with trigonal voids. This extended honeycomb structure can be built by intermolecular imidazole-imidazolate hydrogen bonds of either homochiral $\left(\Delta \Delta \Delta \cdots \cdots\right.$ or $\left.\Lambda \Lambda \Lambda^{\cdots \cdots}\right)$ or heterochiral $(\Delta \Lambda \Delta \cdots)$ arrangement of Mn1 A centers. ${ }^{13}$ The $2 \mathrm{D}$ network of
(A)

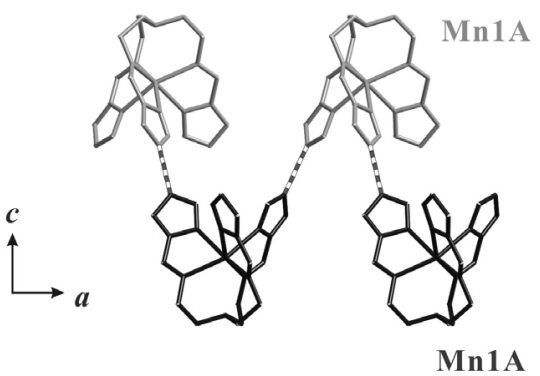

(B)

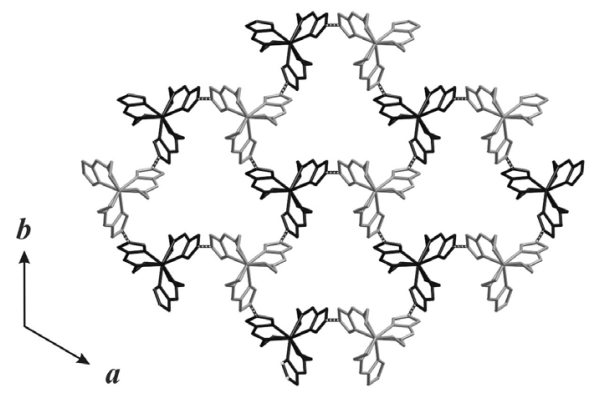

Figure 3. (A) Two pairs of Mn1A centers $\left(=\left[\mathrm{Mn}^{1 \mathrm{~A}}(\mathrm{II}) \mathrm{H}_{1.5} \mathrm{~L}\right]^{0.5+}\right)$ showing the hydrogen bonds (dotted cylinder) of $\mathrm{N}_{\text {imid }}-\mathrm{H} \cdots \cdot \mathrm{N}_{\mathrm{imid}}$ in a tail-to-tail mode and (B) their 2D network. Hydrogen atoms are omitted for clarity. Arrows indicate the axis directions of the crystal unit cell.

Mn1A is constructed in homochiral manner. Similar 2D layer structures have been reported for the crystals of [Co(III) $\left.\mathrm{H}_{1.5} \mathrm{~L}\right]$ $\left(\mathrm{ClO}_{4}\right)_{1.5} \cdot 0.5 \mathrm{H}_{2} \mathrm{O},{ }^{13}\left[\mathrm{Fe}(\mathrm{II}) \mathrm{H}_{3} \mathrm{~L}\right][\mathrm{Fe}(\mathrm{III}) \mathrm{L}]\left(\mathrm{NO}_{3}\right)_{2}{ }_{17}{ }_{17}\left[\mathrm{Fe}(\mathrm{II}) \mathrm{H}_{3} \mathrm{~L}^{\mathrm{Me}}\right]$ $\left[\mathrm{Fe}(\mathrm{II}) \mathrm{L}^{\mathrm{Me}}\right]\left(\mathrm{NO}_{3}\right),{ }^{15}$ and $\left[\mathrm{Fe}(\mathrm{II}) \mathrm{H}_{1.5} \mathrm{~L}\right]\left(\mathrm{BF}_{4}\right)_{0.5},{ }^{17}$ where $\mathrm{H}_{3} \mathrm{~L}^{\mathrm{Me}}$ denotes tris[2-(((2-methylimidazol-4-yl)methylidene)amino) ethyl]amine. The distance between $\mathrm{N}_{\text {imidazole }}$ and $\mathrm{N}_{\text {imidazolate }}$ of the bond $\left(\mathrm{N}_{\text {imid }} \mathrm{H} \cdots \mathrm{N}_{\mathrm{imid}}\right)$ in the Mn1A 2D network is found to be $2.684 \AA$ (Table 3$)$ in agreement of $d\left(\mathrm{~N}_{\text {imid }} \cdots \mathrm{N}_{\text {imid }}\right)=2.68-$ $2.78 \AA$ found in the reported crystals. ${ }^{13-15,17}$

Figure 4 shows two pairs of Mn1B centers and their arrangement. Analogously to the 2D layer consisting of Mn1A centers, the capped tripod-shaped Mn1B centers are stacked in a tailto-tail fashion and up-and-down manner. Each Mn1B center has three hydrogen bonds to $\mathrm{O}$ atoms of water molecules or $\mathrm{ClO}_{4}{ }^{-}$ ions, but these hydrogen bonds are neither further extended nor to form a network. (Figure 4(A)) However, the view of the arrangement of $\mathrm{Mn} 1 \mathrm{~B}$ along the crystal $c$-axis is very similar to a honeycomb shape of puckered 2D network with hexagonal voids. (Figure 4(B)) The network structures of this kind have been reported for the crystals of $\left[\mathrm{Fe}(\mathrm{II}) \mathrm{H}_{3} \mathrm{~L}\right]\left(\mathrm{BF}_{4}\right)_{2} \cdot 3 \mathrm{H}_{2} \mathrm{O}$ and $\left[\mathrm{Ru}(\mathrm{II}) \mathrm{H}_{3} \mathrm{~L}\right]\left(\mathrm{ClO}_{4}\right)_{2} \cdot{ }^{17,20}$ In both the crystals, $\mathrm{N}_{\text {imid }} \mathrm{H} \cdots \mathrm{O} \cdot \cdots \mathrm{H}$ $\mathrm{N}_{\text {imid }}$ hydrogen bonds between two imidazole groups are extended to form $2 \mathrm{D}$ network layer, where the oxygen atom mediating the hydrogen bonds originates from water for $\left[\mathrm{Fe}(\mathrm{II}) \mathrm{H}_{3} \mathrm{~L}\right]\left(\mathrm{BF}_{4}\right)_{2}$. $3 \mathrm{H}_{2} \mathrm{O}$ or $\mathrm{ClO}_{4}{ }^{-}$for $\left[\mathrm{Ru}(\mathrm{II}) \mathrm{H}_{3} \mathrm{~L}\right]\left(\mathrm{ClO}_{4}\right)_{2}$. In the crystal of complex $\mathbf{1}$, such honeycomb shape is formed without the hydrogenbonding network.

Peroxidase activity. Peroxidase activity of complex 1 was examined by observing the oxidation of ABTS by $\mathrm{H}_{2} \mathrm{O}_{2}$ in the presence of complex 1 at $c a$. pH 7..$^{7-9,22}$ ABTS has been used for peroxidase-activity test because its oxidized form, $\mathrm{ABTS}^{+\bullet}$, is a stable green radical with distinct absorption bands at 420 , 
(A)

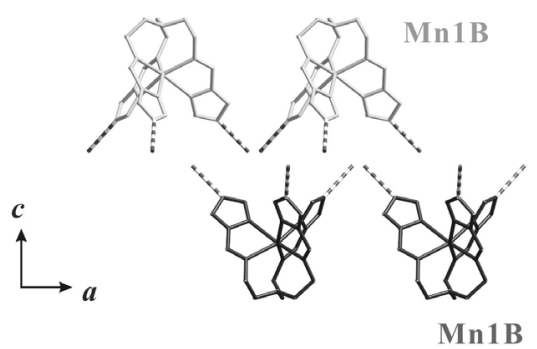

(B)

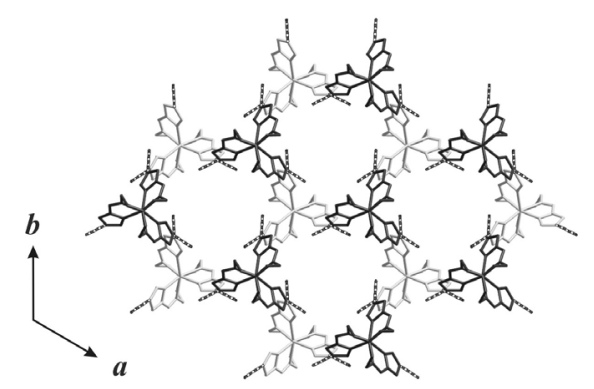

Figure 4. (A) Two pairs of Mn1B centers $\left(=\left[\mathrm{Mn}^{1 \mathrm{~B}}(\mathrm{II}) \mathrm{H}_{3} \mathrm{~L}\right]^{2+}\right)$ with the hydrogen bonds (dotted cylinder) of $\mathrm{N}_{\text {imid }}-\mathrm{H} \cdots \cdot \mathrm{O}_{\text {water or perchloate }}$ and (B) their 2D arrangement. Hydrogen atoms are omitted for clarity. Arrows indicate the axis directions of the crystal unit cell.

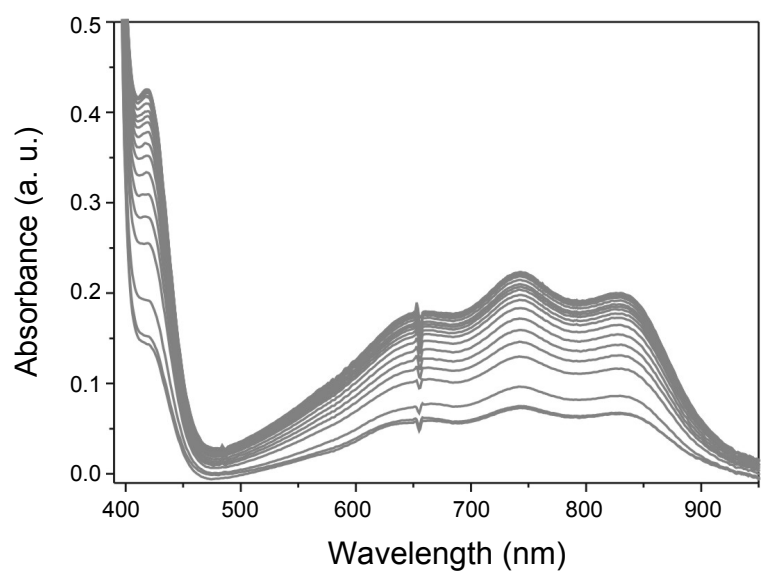

Figure 5. Change of the UV-vis absorption spectra of ABTS $+\mathrm{H}_{2} \mathrm{O}_{2}+$ complex 1 . The reaction was initiated by adding $1 \mathrm{~mL}$ of the methanolic solution of complex $1\left(1.5 \times 10^{-9} \mathrm{~mol}\right.$ of $\left.\left[\mathrm{Mn}(\mathrm{II}) \mathrm{H}_{3} \mathrm{~L}\right]^{2+}\right)$ into $2 \mathrm{~mL}$ of the aqueous solution of $\mathrm{H}_{2} \mathrm{O}_{2}\left(7.5 \times 10^{-7} \mathrm{~mol}\right)$ and ABTS $\left(7.5 \times 10^{-8}\right.$ mol). Each spectrum was obtained every 2 minute up to 60 minutes after mixing. The bottom spectrum was obtained at $0 \mathrm{~min}$ and the top spectrum was obtained at $60 \mathrm{~min}$.

650,740 , and $835 \mathrm{~nm}$ while the reduced form, ABTS, is colorless. $^{7-9,22,28}$ Peroxidase-like reaction was initiated by adding $1 \mathrm{~mL}$ of the methanolic solution of complex $1\left(1.5 \times 10^{-9} \mathrm{~mol}\right.$ of $\left.\left[\mathrm{Mn}(\mathrm{II}) \mathrm{H}_{3} \mathrm{~L}\right]^{2+}\right)$ into $2 \mathrm{~mL}$ of the aqueous solution of $\mathrm{H}_{2} \mathrm{O}_{2}(7.5 \times$ $\left.10^{-7} \mathrm{~mol}\right)$ and $\operatorname{ABTS}\left(7.5 \times 10^{-8} \mathrm{~mol}\right)$.

Figure 5 displays the changes of the absorption features taken every 2 minute till 60 minutes after the mixing. The absorption intensity of $\mathrm{ABTS}^{+\bullet}$ started increasing immediately after the mixing and saturated at $\sim 40$ minutes. Considerable intensity of $\mathrm{ABTS}^{+\bullet}$ was observed at zero minute because $\mathrm{ABTS}^{+\bullet}$ was

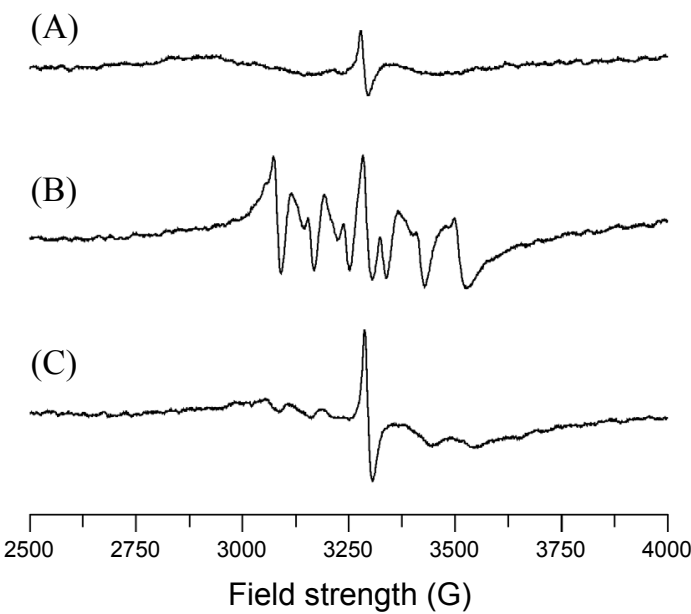

Figure 6. The EPR spectra of (A) ABTS (signal originating from $\mathrm{ABTS}^{+\bullet}$ present as an impurity), (B) ABTS $+\mathrm{H}_{2} \mathrm{O}_{2}+$ complex 1 taken at 4 minutes after the reaction, and (C) ABTS $+\mathrm{H}_{2} \mathrm{O}_{2}+$ complex 1 taken at 40 minutes after the reaction. The reaction was initiated by adding $1 \mathrm{~mL}$ of the methanolic solution of complex $1\left(1.5 \times 10^{-9} \mathrm{~mol}\right.$ of $\left.\left[\mathrm{Mn}(\mathrm{II}) \mathrm{H}_{3} \mathrm{~L}\right]^{2+}\right)$ into $2 \mathrm{~mL}$ of the aqueous solution of $\mathrm{H}_{2} \mathrm{O}_{2}(7.5 \times$ $\left.10^{-7} \mathrm{~mol}\right)$ and ABTS $\left(7.5 \times 10^{-8} \mathrm{~mol}\right)$. Equal volume of ethylene glycol was added into each EPR sample solution for being frozen before EPR measurement. EPR experimental conditions: microwave frequency, $9.22 \mathrm{GHz}$; modulation amplitude, $5 \mathrm{G}$; modulation frequency, $100 \mathrm{kHz}$; time constant, $0.3 \mathrm{sec}$; scan time, 4 minutes; and temperature, $110 \mathrm{~K}$.

present in the original ABTS sample as an impurity, which is also confirmed by the EPR spectrum of ABTS. (see Figure 6) The solutions of ABTS $+\mathrm{H}_{2} \mathrm{O}_{2}$ and ABTS + complex 1 showed the same intensity and features as the spectrum of ABTS + $\mathrm{H}_{2} \mathrm{O}_{2}+$ complex 1 taken at zero minutes and were invariant for several hours. The quantitative amount of the oxidized form, $\mathrm{ABTS}^{+}$, can be estimated from the intensity at $\lambda=650 \mathrm{~nm}$ $\left(\varepsilon_{650}=12,000 \mathrm{~cm}^{-1} \mathrm{M}^{-1}\right) .{ }^{22}$ The difference between the initial and the saturated intensities at $\lambda=650 \mathrm{~nm}$ indicates that the final concentration of $\mathrm{ABTS}^{+}$was $1.0 \times 10^{-5} \mathrm{M}$, implying $3.0 \times$ $10^{-8} \mathrm{~mol}$ of ABTS was oxidized by the reaction.

The generation of $\mathrm{ABTS}^{+\bullet}$ was also monitored by EPR. Figure 6 displays the EPR spectra of ABTS and the reaction mixture. The frozen aqueous solution of ABTS shows some intensity originating from the impurity of $\mathrm{ABTS}^{+}$. (Figure 6(A)) The spectrum taken at 4 minutes after the reaction shows the typical EPR characteristics of the high-spin $\mathrm{Mn}(\mathrm{II})$ ions ( $\mathrm{S}=$ $5 / 2$ ) with ${ }^{55} \mathrm{Mn}$ nuclear hyperfine coupling constant of $\mathrm{A}_{\text {avg }}=$ $87 \mathrm{G}$ centered at $\mathrm{g}=\sim 2$. The intensity of the center line at $\mathrm{g}=$ 2.008 is stronger than the other lines because of $\mathrm{ABTS}^{+\cdot}$ which presents as an impurity and generated by the reaction. (Figure 6(B)) At 40 minutes after the reaction, the Mn(II) EPR signal mostly decays and the increased $\mathrm{ABTS}^{+\bullet}$ signal is shown (Figure $6(\mathrm{C})$ ).

The UV-vis absorption and EPR experiments clearly manifest the oxidation of ABTS by complex $\mathbf{1}+\mathrm{H}_{2} \mathrm{O}_{2}$, neither by complex 1 nor $\mathrm{H}_{2} \mathrm{O}_{2}$. The amount of $\mathrm{ABTS}^{+*}\left(3.0 \times 10^{-8} \mathrm{~mol}\right)$ generated is much more than the amount of $\left[\mathrm{Mn}(\mathrm{II}) \mathrm{H}_{3} \mathrm{~L}\right]^{2+}$ $\left(1.5 \times 10^{-9} \mathrm{~mol}\right)$ though it is not all of ABTS added in the presence of excess $\mathrm{H}_{2} \mathrm{O}_{2}$. This indicates that $\left[\mathrm{Mn}(\mathrm{II}) \mathrm{H}_{3} \mathrm{~L}\right]^{2+}$ has the peroxidase-type catalytic ability.

Because $\left[\mathrm{Mn}(\mathrm{II}) \mathrm{H}_{3} \mathrm{~L}\right]^{2+}$ is fully coordinated, the imidazole 
groups of the ligand should be labile for the completion of the reaction. It is known that the heterocyclic base can ease the homolytic cleavage of $\mathrm{O}-\mathrm{O}$ bond and stabilize $\mathrm{O}=\mathrm{Mn}(\mathrm{IV})$ intermediate. ${ }^{29-31}$ In that sense, one can imagine a monomeric reaction pathway in that $\left[\mathrm{Mn}(\mathrm{II}) \mathrm{H}_{3} \mathrm{~L}\right]^{2+}$ is oxidized by $\mathrm{H}_{2} \mathrm{O}_{2}$ to form $\mathrm{O}=\mathrm{Mn}(\mathrm{IV})$ imtren. $\mathrm{O}=\mathrm{Mn}(\mathrm{IV})$ imtren oxidizes $\mathrm{ABTS}$ to be reduced to another intermediate HO-Mn(III)imtren. And the intermediate again oxidizes ABTS to complete the catalytic cycle. Other possibility is that the hyper-oxidation of $\mathrm{Mn}$ (II) imtren to $\mathrm{O}=\mathrm{Mn}(\mathrm{V})$ imtren and the cycles between $\mathrm{Mn}(\mathrm{V})$ and $\mathrm{Mn}(\mathrm{III})$ exhibited the catalytic activity.

Another possible pathway is the formation of dimanganese intermediates. It has been reported that a mononuclear Mn(II) complex can be dimerized to form a $\mathrm{Mn}(\mathrm{III})-\left(\mu-\mathrm{O}_{2}\right)-\mathrm{Mn}(\mathrm{IV})$ intermediate, which is an active antioxidant species, by $\mathrm{H}_{2} \mathrm{O}_{2}{ }^{32}$ Similarly, catalytic cycles between imtrenMn(III)- $\left(\mu-\mathrm{O}_{2}\right)-\mathrm{Mn}$ (IV)imtren and imtrenMn(II)- $\left(\mu-\mathrm{O}_{2}\right)-\mathrm{Mn}(\mathrm{III})$ imtren might be responsible for the peroxidase activity.

EPR measurements of the intermediates generated during the catalytic reaction might be able to distinguish the reaction pathways because $\mathrm{O}=\mathrm{Mn}(\mathrm{IV}), \mathrm{Mn}(\mathrm{III}) \mathrm{Mn}(\mathrm{IV})$, and $\mathrm{Mn}(\mathrm{II})$ $\mathrm{Mn}$ (III) species are EPR-active. However, we could only detect the reduced intensity of $\mathrm{Mn}$ (II)imtren EPR signal in the course of the reaction. This tends to suggest the formation of $\mathrm{Mn}(\mathrm{V})$ species. But the in-depth studies on the reaction are necessary for the suggestion. Currently, vibration and mass spectroscopic investigations are underway to understand the catalytic mechanism.

\section{Conclusions}

In situ reaction of manganese(II) perchlorate hexahydrate with the condensation mixture of 4-imidazolecarboxaldehyde and tris(2-aminoethyl)amine in dry methanol formed pale yellow solid of complex 1, [Mn(II) $\left.\mathrm{H}_{1.5} \mathrm{~L}\right]_{2}\left[\mathrm{Mn}(\mathrm{II}) \mathrm{H}_{3} \mathrm{~L}\right]_{2}\left(\mathrm{ClO}_{4}\right)_{5}$. $3 \mathrm{H}_{2} \mathrm{O}$, where $\mathrm{H}_{3} \mathrm{~L}$ is tris $\{2$-(4-imidazolyl)methyliminoethyl $\}$ amine. X-ray crystallographic study revealed that the imtren ligand hexadentately binds to $\mathrm{Mn}$ (II) ion through three Schiffbase imine $\mathrm{N}$ atoms and three imidazole $\mathrm{N}$ atoms with distorted octahedral geometry, and the apical tertiary amine $\mathrm{N}$ atom of the ligand pseudo-coordinate to $\mathrm{Mn}(\mathrm{II})$, forming overall a pseudoseven coordination environments. The capped tripod-shaped $\left[\mathrm{Mn}(\mathrm{II}) \mathrm{H}_{1.5} \mathrm{~L}\right]^{0.5+}$ complex ions are hydrogen-bonded in a tailto-tail mode and array in an up-and-down manner repeatedly to honeycomb an extended 2D puckered network with trigonal voids. $\left[\mathrm{Mn}(\mathrm{II}) \mathrm{H}_{3} \mathrm{~L}\right]^{2+}$ complex ions are also stacked in a tail-totail fashion and up-and-down manner. Each $\left[\mathrm{Mn}(\mathrm{II}) \mathrm{H}_{3} \mathrm{~L}\right]^{2+}$ center has three hydrogen bonds to $\mathrm{O}$ atoms of water molecules or $\mathrm{ClO}_{4}{ }^{-}$ions, but these hydrogen bonds are neither further extended nor to form a network. However, the view of the arrangement of $\left[\mathrm{Mn}(\mathrm{II}) \mathrm{H}_{3} \mathrm{~L}\right]^{2+}$ centers along the crystal $c$-axis is very similar to a honeycomb shape of puckered 2D network with hexagonal voids. Two layers are wedged each other to constitute overall stack of the crystal. Peroxidase activity of complex 1 was examined by observing the oxidation of ABTS with hydrogen peroxide in the presence of complex 1 . Generation of ABTS ${ }^{+\bullet}$ was observed by UV-vis and EPR spectroscopies, indicating that the complex 1, a fully-coordinated mononuclear Mn(II) complex with a nitrogen-donor-only ligand, has a heme-independent peroxidase activity.

Acknowledgments. This work was supported by the Korea Research Foundation Grant funded by the Korean Government (KRF-2008-313-C00433). The authors also acknowledge PAL for beam line use (2010-1063-04).

\section{References}

1. Dunford, H. B. Heme Peroxidase; John Wiley \& Sons, Inc.: New York, 1999.

2. Glenn, J. K.; Gold, M. H. Arch. Biochem. Biophys. 1985, $242,329$.

3. Glenn, J. K.; Akileswaran, L.; Gold, M. H. Arch. Biochem. Biophys. 1986, 251, 688.

4. Sundaramoorthy, M.; Kishi, K.; Gold, M. H.; Poulos, T. L. J. Biol. Chem. 1994, 269, 32759.

5. Zou, P. J.; Schrempf, H. Eur. J. Biochem. 2000, 267, 2840.

6. Okrasa, K.; Kazlauskas, R. J. Chem. Eur. J. 2006, 12, 1587.

7. Maneiro, M.; Bermejo, M. R.; Fernandez, M. I.; Gomez-Forneas, E.; Gonzalez-Noya, A. M.; Tyryshkin, A. M. New J. Chem. 2003, 27,727

8. Bermejo, M. R.; Fernandez, M. I.; Gonzalez-Noya, A. M.; Maneiro, M.; Pedrido, R.; Rodriguez, M. J.; Garcia-Monteagudo, J. C.; Donnadieu, B. J. Inorg. Biochem. 2006, 100, 1470.

9. Maneiro, M.; Bermejo, M. R.; Sousa, A.; Fondo, M.; González, A. M.; Sousa-Pedrares, A.; McAuliffe, C. A. Polyhedron 2000, $19,47$.

10. Guilherme, L. R.; Drechsel, S. M.; Tavares, F.; Cunha, C. J. D.; Castaman, S. T.; Nakagaki, S.; Vencato, I.; Bortoluzzi, A. J. J. Mol. Catal. A: Chem. 2007, 269, 22.

11. Dismukes, G. C. Chem. Rev. 1996, 96, 2909.

12. Wu, A. J.; Penner-Hahn, J. E.; Pecoraro, V. J. Chem. Rev. 2004, 104, 903.

13. Katsuki, I.; Motoda, Y.; Sunatsuki, Y.; Matsumoto, N.; Nakashima, T.; Kojima, M. J. Am. Chem. Soc. 2002, 124, 629.

14. Sunatsuki, Y.; Ikuta, Y.; Matsumoto, N.; Ohta, H.; Kojima, M.; Iijima, S.; Hayami, S.; Maeda, Y.; Kaizaki, S.; Dahan, F.; Tuchagues, J.-P. Angew. Chem., Int. Ed. Engl. 2003, 42, 1614.

15. Ikuta, Y.; Ooidemizu, M.; Yamahata, Y.; Yamada, M.; Osa, S.; Matsumoto, N.; Iijima, S.; Sunatsuki, Y.; Kojima, M.; Dahan, F.; Tuchagues, J.-P. Inorg. Chem. 2003, 42, 7001.

16. Brewer, C.; Brewer, G.; Luckett, C.; Marbury, G. S.; Viragh, C.; Beatty, A. M.; Scheidt, W. R. Inorg. Chem. 2004, 43, 2402.

17. Sunatsuki, Y.; Ohta, H.; Kojima, M.; Ikuta, Y.; Goto, Y.; Matsumoto, N.; Iijima, S.; Akashi, H.; Kaizaki, S.; Dahan, F.; Tuchagues, J.-P. Inorg. Chem. 2004, 43, 4154.

18. Lambert, F.; Policar, C.; Durot, S.; Cesario, M.; Yuwei, L.; KorriYoussoufi, H.; Keita, B.; Nadjo, L. Inorg. Chem. 2004, 43, 4178.

19. He, H.; Rodgers, K. R.; Arif, A. M. J. Inorg. Biochem. 2004, 98 , 667.

20. Yamaguchi, T.; Harada, K.; Sunatsuki, Y.; Kojima, M.; Nakajima, K.; Matsumoto, N. Eur. J. Inorg. Chem. 2006, 3236.

21. Brewer, C.; Brewer, G.; Butcher, R. J.; Carpenter, E. F.; Cuenca, L.; Noll, B. C.; Scheidt, W. R.; Viragh, C.; Zavalij, P. Y.; Zielaski, D. Dalton Trans. 2006, 1009.

22. Zipplies, M. F.; Lee, W. A.; Bruice, T. C. J. Am. Chem. Soc. 1986, 108,4433

23. Arvai, A. J.; Nielsen, C. ADSC Quantum-210 ADX Program, Area Detector System Corporation, Poway, CA, USA, 1983.

24. Otwinowski, Z.; Minor, W. In Methods in Enzymology; Carter, J. C. W., Sweet, R. M., Eds.; Academic Press: New York, 1997; 276, Part A, 307.

25. Sheldrick, G. M. SHELXTL-PLUS, Crystal Structure Analysis Package, Bruker Analytical X-Ray, Madison, WI, USA, 1997.

26. Mimura, M.; Matsuo, T.; Motoda, Y.; Matsumoto, N.; Nakashima, T.; Kojima, M. Chem. Lett. 1998, 27, 691.

27. (a) Shannon, R. D.; Prewitt, C. T. Acta Crysts. B 1969, 25, 925, 
(b) Shannon, R. D. Acta Crysts. A 1976, 32, 751.

28. Bermejo, M. R.; Fernandez, M. I.; Gomez-Forneas, E.; GonzalezNoya, A.; Maneiro, M. R.; Pedrido, Rodriguez, M. J. Eur. J. Inorg. Chem. 2007, 24, 3789.

29. Naruta, Y.; Maruyama, K. J. Am. Chem. Soc. 1991, 113, 3595.

30. Balasubramanian, P. N.; Schmidt, E. S.; Bruice, T. C. J. Am. Chem. Soc. 1987, 109, 7865.
31. Balasubramanian, P. N.; Sinha, A.; Bruice, T. C. J. Am. Chem. Soc. 1987, 109, 1456.

32. (a) Lessa, J. A.; Horn, A., Jr.; Bull, E. S.; Rocha, M. R.; Benassi, M.; Catharino, R. R.; Eberlin, M. N.; Casellato, A.; Noble, C. J.; Hanson, G. R.; Schenk, G.; Silva, G. C.; Antunes, O. A. C.; Fernandes, C. Inorg. Chem. 2009, 48, 4569. (b) Naruta, Y.; Sasayama, M.-A.; Sasaki, T. Angew. Chem., Int. Ed. Engl. 1994, 33, 1839. 